\title{
THE INFLUENCE OF IONIZED AIR UPON NORMAL SUBJECTS ${ }^{1}$
}

\author{
By L. P. HERRINGTON
}

(From the John B. Pierce Laboratory of Hygiene, New Haven)

(Received for publication September 7, 1934)

Dessauer and his associates in Germany (1) have published a series of papers on the effects of artificially ionized air on normal and pathological subjects, which have aroused considerable interest among students of ventilation. The results obtained indicate that positive and negative ions produce, respectively, opposite physiological and subjective effects. Positive ions seem to increase the respiratory rate, basal metabolism and blood pressure, and in general produce unpleasant subjective symptoms. Subjects in the Dessauer experiments complained of headache, a sense of fatigue, nausea, dizziness, and general malaise when exposed to these positive ions. Negative ions, on the other hand, decrease the physiological functions mentioned above, and were often accompanied by a feeling of exhilaration and well being.

The most striking results were claimed in the treatment of cases of essential hypertension uncomplicated by renal or cardiac disease. With this group of subjects a considerable reduction of blood pressure after repeated exposure to negative ions was reported. This reduction tends to persist for some time after the cessation of the treatment and the treatment was considered as of fundamental therapeutic importance. The reported data on normal subjects is less extensive, but in general seem inconclusive except with respect to the subjective symptoms.

Küster (6), working in another department of the University at Frankfort, claimed similar effects upon metabolism under practical conditions of ventilation as a result of the use of an airconditioning system producing smaller negative ions.

The problem of atmospheric ionization in relation to health and ventilation has been dealt with by Yaglou and his associates at Harvard University. In two of the papers of this series (2) (4) extensive data were reported on the physiological

1 Contribution No. 3, John B. Pierce Laboratory of Hygiene. and subjective changes in human subjects after exposure to artificially ionized air (ions of the small molecular type were used). The data seemed to substantiate in part Dessauer's report of the subjective reactions. The physiological findings do not agree with those of the Germans as they show no relation to the sign of the ion used, or, within limits, to the concentration. In the first of these two papers (4) the authors, however, suggest that their data on total metabolism, respiratory rate, pulse rate, and blood pressure before and after ionization indicate a normalizing effect of ionized air (irrespective of polarity) on these physiological functions. In other words, if blood pressure, for example, were high, ions of either sign tended to lower it-if low, they tended to raise it. In the second paper (2) the authors state that "subsequent experiments with improved apparatus have not entirely confirmed our preliminary observations and Dessauer's conclusions"; and that "under the conditions of the present experiments nothing definite was found to justify the use of artificial ionization in general ventilation."

It should be mentioned that the Dessauer studies were made with an apparatus which supplied artificially ionized air (of either polarity) in which the ions consisted largely of charged submicroscopic particles of magnesium oxide dust with a motility range from .007 to .0018 centimeters per second per volt per centimeter. In some instances the entire air of the experimental room was charged, in others the ionized air was delivered through a funnel placed over the subject's face. Ion counts were usually $10^{6}$ ions per cubic centimeter or more. Ions in this range of motility reach the lungs in the inspired air and are precipitated there in considerable quantities. The actual amount of transported material, magnesium oxide, is very minute. In the course of a half hour's respiration of ionized air about .33 mgm. of solid material is inhaled, of which about $.005 \mathrm{mgm}$. of charged material is retained (Dessauer (1)). 
In the studies of Yaglou and his associates the ions used were of the small molecular type having on the average a motility of 1.3 centimeter per volt per centimeter in the breathing zone of the experimental chamber. According to Dessauer ions of this type do not reach the lungs. The external surfaces of the subject, however, are exposed to their action.

The results of the researches mentioned here indicate that the physiological effects of artificially ionized air on normal subjects, if any, are of small degree and subtle in character. Dessauer's published data on normal subjects (using large ions) are scanty and certainly do not indicate any very striking effects. Küster's results are suggestive but may well have been due to some factor other than ionization since what he was comparing was really a room atmosphere with and without air conditioning. Yaglou's last results seem to be negative, but he worked only with small ions which Dessauer believes to be without important influence.

It would certainly seem that rather large ions of the Dessauer type which can penetrate most deeply into the lungs should be in position to produce a maximum effect. It seemed to us, therefore, desirable to apply the Dessauer technique in an intensive study of a group of normal subjects of as nearly comparable physical status as possible (health, age, sex, etc.). Such a study should be thoroughly controlled from a psychological standpoint and sufficiently prolonged to allow of an opportunity for the appearance of cumulative effects. The present program has been undertaken in an effort to close this gap in the literature on the subject.

\section{APPARATUS AND METHOD OF ADMINISTRATION}

The ion generator used in the present study was identical with that used in the more recent Dessauer studies, and was constructed at the Institute of Experimental Medicine at the University of Frankfurt-am-Main. The apparatus is fully described in the principle Dessauer reference (1). It consists essentially of an elongated glass container through which 1 to 2 liters of filtered air per second are blown. Situated in this container is a small block of pressed magnesium oxide which is heated by a platinum coil to a temperature of about $950^{\circ} \mathrm{C}$. Large numbers of ions of both polarities are given off from this iondonator to the passing air. Ions of the undesired sign are filtered out as the air stream passes through a wire grid which is charged to a high potential of appropriate polarity. The unipolar air stream is cooled as it passes through a tube in a water bath and delivered through a glass tube to the experimental chamber. The ionic content of the air stream is measured as it leaves the cooling coil with a suitably calibrated silver leaf electroscope. The ionic concentration at this point is from 1.7 to $2.0 \times 10^{7}$ positive or negative ions, with mobilities in the range of from .007 to .0018 centimeters per second per volt per centimeter. They consist largely of charged submicroscopic particles of magnesium oxide.

The ions were administered to the subjects in our experiments by leading the air stream in $a^{\prime}$ glass tube through a wall into a small metabolism room which adjoined the laboratory in which the generator was set up. Here subjects reclined comfortably on adjustable beds and breathed the ionized air which was directed on to the face by funnels which fitted loosely over the head and assured a high concentration of ions in the breathing zone. Two subjects could be accommodated at a time. The temperature of the metabolism room was maintained at approximately $70^{\circ} \mathrm{F}$., with normal indoor humidities.

Ion counts made in the breathing zone showed a concentration of 5 to $6 \times 10^{6}$ ions $(5,000,000$ to $6,000,000$ ) per cubic centimeter. These counts were made with a portable ion counter similar to that used by the Dessauer group (1). After 30 minutes ionization the concentration of ions in the middle of the room was about $.5 \times 10^{6}$ (500,$000)$ per cubic centimeter. When the ion generator was turned off this concentration fell in 15 minutes to $.1 \times 10^{8}(100,000)$ per cubic centimeter. After 30 minutes the count had a usual value of .04 to $.07 \times 10^{8}(40,000$ to 70,000$)$ per cubic centimeter. The counts were about the same for negative and positive ions. When positive ionization was used the count for negative ions was practically zero, and vice versa.

\section{EXPERIMENTAL ROUTINE}

Each subject was contracted with for a program of 15 or more separate experiments, each experiment to be performed on a separate day and 
the series to be completed in two to three months. Subjects were paid for their services. Each subject was expected twice a week, but it was understood that this routine would be interrupted if minor illness, overwork, or some special indulgence or recreation had occurred on the day or night previous to the experiment. As the subjects were, with one exception, all medical students, the significance of these instructions was appreciated and intelligent cooperation elicited.

Only male subjects were used. They ranged in age from 18 years 8 months to 25 years 8 months. All were in excellent health and had been pronounced normal on recent medical examination. Two subjects had suffered rheumatic attacks 4 to 5 years earlier. Previous to the actual experimentation each subject was put through the entire routine and the data discarded. None of the subjects were told that the experiment was concerned with the effects of ionized air. Most of them learned of it before the experiment was finished. The novelty of the experimental situation had so completely worn off by this time that none of them showed any real concern as to the matter. Each subject spent from 55 to 60 hours in test periods of $3 \frac{1}{2}$ hours at rest and without decided movement or conversation.

The experiments were divided into two groups (1) a morning group under standard basal conditions, and (2) an afternoon group tested after a standard low calorie lunch taken at 12 o'clock at the laboratory and followed by a rest period of two hours after which tests were made.

Six subjects comprised the morning group. They arrived in teams of two at the laboratory at 10 o'clock on the night preceding the morning tests. They slept until 6 a.m. in the comfortably equipped test rooms of the laboratory which were held at a temperature of approximately $60^{\circ} \mathrm{F}$. At 6 a.m. they were awakened, allowed to urinate, and transferred to the metabolism room. After 45 minutes the test routine was begun. Thirty minutes before this routine began the motor blower of the ion generator had been turned on in order to adapt the subject to the slight hum of the motor and the sensation of moving air on the face.

The afternoon group consisted of 5 subjects. The subjects took a light breakfast on the day of the test and arrived at the laboratory at noon. They were given a low calorigenic lunch (Benedict and Benedict (3)) consisting of

1 cup (200 cc.) of caffeine-free coffee,

$16 \mathrm{mgm}$. of saccharine,

30 grams of medium cream,

25 grams of potato chips,

and immediately reclined on the beds in the metabolism room and rested until 2:00 p.m., and after this rest period tests were begun.

No variation whatsoever was permitted from this routine. Subjects arriving late or reporting strenuous activity were dismissed and taken on another date. Under these regulations subjects in both morning and afternoon groups showed minimal variations in the physiological functions measured and there is no doubt that extraneous factors were eliminated to a very high degree.

The following observations were made during each experimental period. Basal or total metabolism (depending upon whether the morning or afternoon group is considered), blood pressure, respiratory rate, pulse rate, oral temperature, and total urine volue. At the end of the experiment subjects were given an opportunity to comment on their subjective state.

The experimental program as a whole was divided, for each subject, into three series of 5 experiments each, which gave a total of 15 separate experimental periods for every subject. In the first series of 5 experiments, designated as the Positive Series, the subject received positive ions during a period of ionization preceded and followed by control periods. The second series of 5 experiments was identical except that negative ions were administered in the middle period. In the third series, no variation was made from the previous routine except that the air stream during the middle period contained no ions.

Each single experimental session of the 15 was thus divided into 3 periods.

a. First normal. Thirty minutes before the end of the preliminary rest period the motor blower was turned on and the subject allowed to rest with the air stream blowing on his face. (The air supplied was filtered air from the laboratory-no ions were added.) At the end of this period, oral temperature, pulse rate, blood pres- 
sure, and metabolism were taken in the order named.

b. Test period. As soon as the last measurement had been taken in the first normal period either positive (Series 1) or negative (Series 2) ions or no ions at all (Series 3 ) were added to the air stream and the subject allowed to breathe the ionized or un-ionized air for 30 minutes. The routine observations were repeated at the end of this period.

c. Second normal. As soon as the measurements in period $(b)$ had been completed the heating current on the ion-donators was shut off and the subject allowed to breathe un-ionized air as in the first normal period. After 30 minutes the observations were repeated as in periods $(a)$ and (b).

Subjects were then questioned as to their subjective state on which they were allowed free comment. At this point, they visited the washroom and reported the total urine volume. This concluded the experiment.

The temperature and velocity of the air stream was carefully regulated so that there would be no cues which might distinguish the ion period from the two normal periods. In like manner the Positive, Negative and Control Series, as groups, were carried out with identical technique. It should be mentioned that the Control Series was divided into 3 periods and treated precisely as if the midperiod had contained ions.

Metabolism was determined by the closed circuit oxygen consumption method using the Benedict-Roth apparatus. Most of the subjects were familiar with the technique and yielded satisfactory records.

Blood pressure was determined by the auscultatory method using a mercury manometer. The first clear sound was taken as the systolic pressure and the beginning of the fourth phase as the diastolic pressure.

\section{RESULTS}

The only deviation from the program outlined above consisted in 3 series of 4 experiments each rather than 5 each carried out on 2 of the 11 subjects. In all 159 experiments were made, of which 90 were on morning subjects and 69 on afternoon subjects. There was no important difference between the two sets of records except that the steady states for the various measures tended to be slightly higher for the afternoon group. In view of this similarity the results for the two groups have been consolidated.

Three types of controls are incorporated in the data. (1) Normal control periods preceding and following the ion period in each individual test. (2) A complete Control Series duplicating the Positive and the Negative Series. (3) Contrast control, consisting of a comparison of the changes during ion periods in the Positive Series with those occurring during the ion period in the Negative Series.

In Table I are reproduced the complete data for the Positive Series on one subject, Wi. It can readily be seen from this typical case that while variations do occur in individual experiments which are suggestive, they lose their significance

TABLE I

Complete data on Positive Series. (Subject Wi)

\begin{tabular}{|c|c|c|c|c|c|c|c|c|c|c|c|c|c|c|c|c|c|c|c|}
\hline \multirow{2}{*}{$\begin{array}{l}\text { Ex- } \\
\text { peri- } \\
\text { ment } \\
\text { num- } \\
\text { ber }\end{array}$} & \multirow{2}{*}{$\begin{array}{l}\text { Date } \\
\text { of ex- } \\
\text { peri- } \\
\text { ment }\end{array}$} & \multirow{2}{*}{$\begin{array}{l}\text { Sub- } \\
\text { ject }\end{array}$} & \multirow{2}{*}{ Series } & \multirow{2}{*}{$\mid \begin{array}{l}\text { Room } \\
\text { tem- } \\
\text { pera- } \\
\text { ture }\end{array}$} & \multicolumn{3}{|c|}{ Blood pressure } & \multicolumn{3}{|c|}{ Pulse rate } & \multicolumn{3}{|c|}{ Respiration rate } & \multicolumn{2}{|c|}{$\begin{array}{c}\text { Oral } \\
\text { temperature }\end{array}$} & \multicolumn{3}{|c|}{$\begin{array}{c}\text { Metabolic rate } \\
\text { Total calories per } \\
\text { hour }\end{array}$} & \multirow{2}{*}{$\begin{array}{c}\text { Urine } \\
\text { volume }\end{array}$} \\
\hline & & & & & 1 & 2 & 3 & 1 & 2 & 3 & 1 & 2 & 3 & 1 & 3 & 1 & 2 & 3 & \\
\hline & 1994 & & & ${ }^{\circ} \mathrm{F}$. & $\underset{\boldsymbol{H} \boldsymbol{g}}{m_{m}}$ & $\underset{H \boldsymbol{g}}{m_{\boldsymbol{B}}}$ & $\underset{H \boldsymbol{g}}{\operatorname{mm}}$ & $\underset{\substack{p e r \\
\text { mite }}}{\text { uer }}$ & $\begin{array}{l}\text { per } \\
\text { min- } \\
\text { ute }\end{array}$ & $\underset{\substack{\text { per } \\
\text { min- }}}{\text { ute }}$ & $\begin{array}{c}\text { per } \\
\text { min- } \\
\text { ute }\end{array}$ & $\begin{array}{c}\text { per } \\
\text { min- } \\
\text { ute }\end{array}$ & $\begin{array}{c}\text { per } \\
\text { min- } \\
\text { ute }\end{array}$ & ${ }^{\circ} \mathrm{F}$. & ${ }^{\circ} \mathrm{F}$. & $\begin{array}{l}\text { cal- } \\
\text { ories }\end{array}$ & $\begin{array}{l}\text { cal- } \\
\text { ories }\end{array}$ & $\begin{array}{c}\text { cal- } \\
\text { ories }\end{array}$ & $c c$. \\
\hline 90 & $2 / 15$ & Wi & + & 71/70 & $98 / 68$ & $108 / 74$ & $112 / 78$ & 60 & 66 & 72 & 8 & 8 & 7 & 98.2 & 98.2 & 76.3 & 77.9 & $\mid 76.3$ & 430 \\
\hline 111 & $2 / 22$ & Wi & + & $71 / 69$ & $\mid 104 / 62$ & $100 / 68$ & $102 / 70$ & 60 & 63 & 60 & 10 & 9 & 9 & 97.6 & 97.8 & 78.0 & 72.5 & 72.5 & 510 \\
\hline 117 & $3 / 1$ & Wi & + & $73 / 75$ & $|100 / 66|$ & $104 / 68$ & $\mid 104 / 64$ & 64 & 62 & 66 & 10 & 9 & 6 & 97.5 & 97.7 & 78.1 & 79.6 & 79.4 & 270 \\
\hline 127 & $3 / 6$ & Wi & + & 69/69 & $108 / 66$ & $108 / 66$ & $106 / 70$ & 67 & 64 & 62 & 8 & 9 & 8 & 97.7 & 97.6 & 78.4 & 73.9 & 74.6 & 460 \\
\hline 135 & $3 / 8$ & Wi & + & $70 / 70$ & | $98 / 66$ & $102 / 68$ & $102 / 66$ & 63 & 63 & 60 & 13 & 8 & 9 & 97.8 & 97.6 & 73.7 & 73.5 & 71.5 & 640 \\
\hline
\end{tabular}


on repeated observation. For example, the basal metabolic rate is increased in the Positive Series in Experiment 90, but decreased in Experiment 111. Repetition of the experiment, however, defines these differences as lying well within the range of normal variability.

It is impractical to reproduce all of the original data here. They can be illustrated, however, by abstracting the most significant variations in the data for individual subjects. In Table III, I have summarized these data on metabolic rate for individual cases. It is assumed that since all of the functions measured show a considerable variability the proper evaluation of such differences as do occur should involve the employment of the accepted statistical techniques for interpreting mean differences between measurements made under control and experimental situations.

TABLE II

Consolidated results for one subject-N

(Each figure is the mean of $\mathbf{5}$ observations and is accompanied by its standard deviation.)

\begin{tabular}{l|c|c|c|c}
\hline $\begin{array}{c}\text { Experimental } \\
\text { series }\end{array}$ & $\begin{array}{c}\text { Number } \\
\text { of exper- } \\
\text { iments }\end{array}$ & $\begin{array}{c}\text { 1st period } \\
\text { normal }\end{array}$ & $\begin{array}{c}\text { 2d period } \\
\text { ions }\end{array}$ & $\begin{array}{c}\text { 3d period } \\
\text { normal }\end{array}$ \\
\hline \multicolumn{3}{c}{ Blood pressure-Systolic, mm. $H g$} \\
\hline Positive.... & 5 & $104 \pm 4.1$ & $105 \pm 2.6$ & $105 \pm 2.6$ \\
Negative... & 5 & $100 \pm 2.1$ & $100 \pm 4.1$ & $102 \pm 1.6$ \\
Control.... & 5 & $103 \pm 3.5$ & $103 \pm 4.7$ & $103 \pm 3.3$ \\
\hline
\end{tabular}

Blood pressure-Diastolic, $\mathrm{mm}$. $\mathrm{Hg}$

\begin{tabular}{l|l|l|l|l}
\hline Positive.... & 5 & $70 \pm 4.2$ & $71 \pm 3.9$ & $70 \pm 2.2$ \\
Negative... & 5 & $67 \pm 2.1$ & $62 \pm 3.5$ & $68 \pm 3.0$ \\
Control.... & 5 & $68 \pm 3.2$ & $70 \pm 4.3$ & $66 \pm 3.0$ \\
\hline
\end{tabular}

Basal metabolism-total calories per hour

\begin{tabular}{l|l|l|l|l}
\hline Positive.... & 5 & $59.6 \pm 2.3$ & $61.4 \pm 4.4$ & $61.7 \pm 2.6$ \\
Negative... & 5 & $65.4 \pm 4.4$ & $61.2 \pm 4.2$ & $62.0 \pm 3.6$ \\
Control.... & 5 & $62.1 \pm 1.9$ & $61.2 \pm 1.6$ & $61.1 \pm 3.3$ \\
\hline
\end{tabular}

Respiration rate-per minute

\begin{tabular}{|c|c|c|c|c|}
\hline $\begin{array}{l}\text { Positive. . . } \\
\text { Negative. . } \\
\text { Control... . }\end{array}$ & $\begin{array}{l}5 \\
5 \\
5\end{array}$ & $\begin{array}{r}11.0 \pm .6 \\
10.0 \pm .6 \\
9.4 \pm 1.2\end{array}$ & $\begin{array}{r}10.6 \pm . \\
9.8 \pm .8 \\
9.6 \pm .\end{array}$ & $\begin{array}{c}11.0 \pm 0 . \\
9.8 \pm .4 \\
9.6 \pm .5\end{array}$ \\
\hline
\end{tabular}

Pulse rate-per minute

\begin{tabular}{l|l|l|l|l}
\hline Positive.... & 5 & $53.4 \pm 2.2$ & $49.0 \pm 2.6$ & $48.6 \pm 3.3$ \\
Negative... & 5 & $52.6 \pm 2.4$ & $50.2 \pm 2.6$ & $51.8 \pm 3.7$ \\
Control.... & 5 & $50.0 \pm 1.3$ & $50.4 \pm .63$ & $50.8 \pm 1.2$ \\
\hline
\end{tabular}

The most convenient device for this purpose is the ratio of difference observed between compared means to the standard deviation of the difference (Rugg (5)). This is often called the Critical Ratio. Critical Ratios above 3 are usually accepted as indicating that some constant factor has entered into the values forming the one mean which was not present in the other case. The formula is :

$$
\frac{D}{\sqrt{S D^{2} M_{1}+S D^{2} M_{2}}}=\text { Critical Ratio. }
$$

In this formula $D$ is the difference between the two mean values. $S D_{M_{1}}$ is the standard deviation of one mean, $S D_{M_{2}}$ the standard deviation of the second mean.

TABLE III

Maximum change $\dagger$ in metabolic rate (in total calories per hour)

\begin{tabular}{|c|c|c|c|c|c|}
\hline \multirow{2}{*}{ Subject } & \multirow{2}{*}{ Series } & \multirow{2}{*}{ Period 1} & \multicolumn{2}{|c|}{ Maximum change } & \multirow{2}{*}{$\begin{array}{l}\text { Critical } \\
\text { ratio }\end{array}$} \\
\hline & & & Period & & \\
\hline 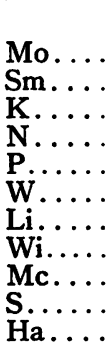 & $\begin{array}{l}- \\
+ \\
\bar{t} \\
+ \\
\mathbf{c} \\
+ \\
+ \\
+ \\
-\end{array}$ & $\begin{array}{r}\text { mean } \pm S . D . \\
* 58.3 \pm 3.0 \\
68.4 \pm 3.6 \\
58.7 \pm 2.4 \\
65.4 \pm 4.4 \\
60.4 \pm 2.1 \\
65.7 \pm 3.0 \\
72.1 \pm 3.3 \\
77.7 \pm .8 \\
72.5 \pm 2.6 \\
74.6 \pm 3.2 \\
72.3 \pm 4.5\end{array}$ & $\begin{array}{l}2 \\
2 \\
2 \\
2 \\
2 \\
2 \\
3 \\
2 \\
2 \\
2 \\
3\end{array}$ & $\begin{array}{r}\text { mean } \pm S . D . \\
* 62.0 \pm 2.5 \\
70.5 \pm 3.7 \\
63.3 \pm 1.3 \\
62.1 \pm 4.2 \\
64.2 \pm 2.8 \\
68.1 \pm 9.7 \\
67.8 \\
74.3 \pm 2.8 \\
75.3 \pm 3.6 \\
69.5 \pm 4.7 \\
79.5 \pm 4.0\end{array}$ & $\begin{array}{l}2.06 \\
.91 \\
3.83 \\
1.22 \\
2.38 \\
.52 \\
2.69 \\
2.61 \\
1.27 \\
1.82 \\
2.67\end{array}$ \\
\hline
\end{tabular}

* Each figure is the mean of 5 measurements of metabolism.

$\dagger$ Maximum change - each comparison in this table, and in Tables III, IV, V, VI was obtained from tabulations of the consolidated results of each subject. See Table II.

Of 5 positive period changes 3 were increases, 2 decreases.

Of 5 negative period changes 3 were increases, 2 decreases.

Of 1 control period change 1 was an increase, 0 decreases.

In Table III are presented also the Critical Ratios for the greatest difference in metabolic rate between the mean of any first normal period and the mean of any succeeding period for each subject. (The means of the first normal periods were the means of the five first normal periods for each of the three series.) The notation under 
Periods indicates where the variation occurs: Example: Subject Mo (1, 2, -) indicates that the greatest change within a series from the mean for the first normals occurred in the mean for the ion periods in the Negative Series. In Subject W $(1,2, C)$ the greatest change occurs between the first normal mean and 2 period mean in the Control Series. Only one subject showed a change of possible statistical significance, a barely significant increase of metabolic rate, on exposure to positive ions, all others having a Critical Ratio below 3. As shown in the tabulation at the bottom of the table, an analysis of the direction of change in the three series shows no consistency.

TABLE IV

Maximum change in respiratory rate (per minute)

\begin{tabular}{|c|c|c|c|c|c|}
\hline \multirow{2}{*}{ Subject } & \multirow{2}{*}{ Series } & \multirow{2}{*}{ Period 1} & \multicolumn{2}{|c|}{ Maximum change } & \multirow{2}{*}{$\begin{array}{c}\text { Critical } \\
\text { ratio }\end{array}$} \\
\hline & & & Period & & \\
\hline $\begin{array}{l}\text { Sm } \ldots . . \\
\text { Mo... } \\
\mathbf{P} \ldots \ldots \\
\mathbf{K} \ldots \ldots \\
\mathbf{N} \ldots \ldots \\
\mathbf{W} \ldots \ldots \\
\mathbf{L i} \ldots \ldots \\
\mathbf{W i} \ldots \ldots \\
\mathbf{M c} \ldots \ldots \\
\mathbf{S} \ldots \ldots \\
\mathbf{H a} \ldots \ldots\end{array}$ & $\begin{array}{l}\text { C } \\
\text { C } \\
\text { C } \\
\text { C } \\
+ \\
+ \\
+ \\
\text { C } \\
\text { C } \\
+ \\
+\end{array}$ & $\begin{array}{r}\text { mean } \pm S . D . \\
11.4 \pm .8 \\
11.5 \pm .8 \\
8.2 \pm 1.9 \\
14.6 \pm 1.0 \\
11.0 \pm .6 \\
9.0 \pm 2.1 \\
14.5 \pm 2.1 \\
10.2 \pm 1.5 \\
10.5 \pm 1.1 \\
12.5 \pm 1.1 \\
16.8 \pm 1.0\end{array}$ & $\begin{array}{l}3 \\
3 \\
2 \\
3 \\
2 \\
3 \\
3 \\
3 \\
2 \\
3 \\
3\end{array}$ & $\begin{array}{r}\text { mear } \pm S . D . \\
12.6 \pm .8 \\
9.6 \pm 1.0 \\
7.6 \pm .8 \\
15.6 \pm .5 \\
10.6 \pm .8 \\
7.0 \pm 1.1 \\
16.4 \pm 1.8 \\
7.0 \pm 1.1 \\
12.5 \pm 1.1 \\
10.8 \pm .8 \\
22.0 \pm 3.0\end{array}$ & $\begin{array}{r}2.35 \\
3.28 \\
.64 \\
2.00 \\
.87 \\
.20 \\
1.46 \\
3.95 \\
2.53 \\
2.57 \\
2.29\end{array}$ \\
\hline
\end{tabular}

Of 1 negative period change, 1 was an increase.

Of 4 positive period changes, 1 was an increase, 3 decreases.

Of 6 control period changes, 3 were increases, 3 decreases.

In Table IV are reported the corresponding data for respiratory rate. Only two subjects Mo and $\mathrm{Wi}$ show statistically significant changes between mean values of first normals and succeeding periods. Both these changes, however, occurred between the first and third periods in the Control Series when no ions were used.

In Table $\mathrm{V}$ is an analysis of similar data for pulse rate. Two subjects, $\mathrm{K}$ and $\mathrm{Ha}$, show statistically significant changes between the mean of the first normals in the positive period and the mean of the second period (positive ions). Note that the changes for the two subjects are in opposite directions. In six instances the largest
TABLE V

Maximum change in pulse rate (per minute)

\begin{tabular}{|c|c|c|c|c|c|}
\hline \multirow{2}{*}{ Subject } & \multirow{2}{*}{ Series } & \multirow{2}{*}{ Period 1} & \multicolumn{2}{|c|}{ Maximum change } & \multirow{2}{*}{$\begin{array}{l}\text { Critical } \\
\text { ratio }\end{array}$} \\
\hline & & & Period & & \\
\hline $\begin{array}{l}\text { Sm.... } \\
\text { Mo... } \\
\mathbf{N} \ldots \ldots \\
\mathbf{K} \ldots \ldots \\
\mathbf{P} \ldots \ldots \\
\mathbf{W} \ldots \ldots \\
\mathbf{L i} \ldots \ldots \\
\text { Wi..... } \\
\text { Mc.... } \\
\text { S. ..... } \\
\text { Ha.... }\end{array}$ & $\begin{array}{l} \pm \\
\pm \\
+ \\
\frac{+}{+} \\
+ \\
\frac{+}{+} \\
+ \\
+\end{array}$ & $\begin{array}{l}\text { mean } \pm \text { S.D. } \\
51.6 \pm 1.7 \\
57.0 \pm 1.4 \\
53.4 \pm 2.2 \\
65.8 \pm 2.8 \\
51.6 \pm 3.2 \\
53.8 \pm 3.2 \\
64.0 \pm 5.1 \\
65.6 \pm 3.5 \\
66.5 \pm 2.6 \\
64.0 \pm 1.42 \\
72.8 \pm 2.6\end{array}$ & $\begin{array}{l}3 \\
3 \\
3 \\
3 \\
3 \\
3 \\
3 \\
3 \\
3 \\
3 \\
2\end{array}$ & $\begin{array}{l}\text { mean } \pm S . D . \\
55.8 \pm 3.9 \\
61.4 \pm 4.2 \\
48.6 \pm 3.3 \\
71.6 \pm 3.0 \\
56.4 \pm 3.5 \\
55.8 \pm 3.2 \\
61.2 \pm 5.0 \\
68.2 \pm 3.7 \\
62.2 \pm 3.0 \\
62.5 \pm 2.2 \\
65.0 \pm 3.7\end{array}$ & $\begin{array}{l}2.21 \\
2.20 \\
2.67 \\
3.22 \\
2.29 \\
1.00 \\
.85 \\
1.13 \\
2.39 \\
1.25 \\
3.71\end{array}$ \\
\hline
\end{tabular}

Of 3 negative period changes, 2 were increases, 1 a decrease.

Of 6 positive period changes, 2 were increases, 4 decreases.

Of 2 control period changes, 2 were increases, 0 decreases.

change occurred in the Positive Series, in two instances in the Negative Series, and three times in the Control Series.

TABLE VI

Maximum change in systolic blood pressure (in $\mathrm{mm}$. of $\mathrm{Hg}$ )

\begin{tabular}{|c|c|c|c|c|c|}
\hline \multirow{2}{*}{ Subject } & \multirow{2}{*}{ Series } & \multirow{2}{*}{ Period 1} & \multicolumn{2}{|c|}{ Maximum change } & \multirow{2}{*}{$\begin{array}{l}\text { Critical } \\
\text { ratio }\end{array}$} \\
\hline & & & Period & & \\
\hline $\begin{array}{l}\text { Ha.... } \\
\text { Mo.... } \\
\text { S..... } \\
\text { Sm.... } \\
\text { Wi.... } \\
\text { Mc.... } \\
\text { Li. ... } \\
\text { W.... } \\
\text { N. . . } \\
\text { K . . . } \\
\text { P.... }\end{array}$ & $\begin{array}{l} \pm \\
- \\
\bar{C} \\
c \\
\pm \\
\frac{1}{-} \\
\bar{c} \\
-\end{array}$ & $\begin{array}{r}\text { mean } \pm S . D . \\
111 \pm 9.8 \\
96 \pm 5.3 \\
117 \pm 1.0 \\
114 \pm 1.5 \\
101 \pm 4.1 \\
112 \pm 2.8 \\
104 \pm 6.6 \\
95 \pm 3.7 \\
100 \pm 2.2 \\
98 \pm 2.4 \\
99 \pm 4.4\end{array}$ & $\begin{array}{l}2 \\
3 \\
2 \\
3 \\
2 \\
2 \\
2 \\
3 \\
3 \\
3 \\
3\end{array}$ & $\begin{array}{r}\text { mean } \pm S . D . \\
106 \pm 2.2 \\
103 \pm 7.4 \\
111 \pm 4.1 \\
122 \pm 7.7 \\
105 \pm 2.1 \\
107 \pm 5.0 \\
99 \pm 2.1 \\
98 \pm 2.4 \\
102 \pm 1.6 \\
101 \pm 2.1 \\
104 \pm 3.2\end{array}$ & $\begin{array}{l}1.11 \\
.39 \\
2.86 \\
2.29 \\
1.90 \\
1.72 \\
1.61 \\
1.50 \\
1.67 \\
2.14 \\
2.08\end{array}$ \\
\hline
\end{tabular}

Of 5 negative period changes, 4 were increases, 1 decrease.

Of 2 positive period changes, 0 were increases, 2 decreases.

Of 4 control period changes, 3 were increases, 1 decrease.

The data of Table VI indicate that no subject showed a change in mean systolic pressure large enough to give a Critical Ratio of 3. Two subjects showed the most significant changes in the 
Positive Series, five in the Negative Series, and four in the Control Series.

Table VII gives the corresponding data for diastolic pressure. Four subjects, $\mathrm{Ha}, \mathrm{Sm}, \mathrm{Wi}$ and $W$, showed changes with Critical Ratios over 3. Two of these changes occurred between periods in the solid Control Series, one between the first and last normal periods in the Positive Series, and one between the first and last periods in the Negative Series. Both of the latter were increases.

TABLE VII

Maximum change in diastolic blood pressure (in $\mathrm{mm}$. of $\mathrm{Hg}$ )

\begin{tabular}{|c|c|c|c|c|c|}
\hline \multirow{2}{*}{ Subject } & \multirow{2}{*}{ Series } & \multirow{2}{*}{ Period 1} & \multicolumn{2}{|c|}{ Maximum change } & \multirow{2}{*}{$\begin{array}{c}\text { Critical } \\
\text { ratio }\end{array}$} \\
\hline & & & Period & & \\
\hline 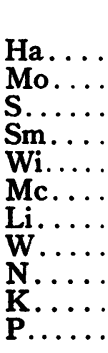 & $\begin{array}{l}\frac{+}{1} \\
+ \\
\text { C } \\
\text { C } \\
\frac{-}{-} \\
\bar{C} \\
\text { C }\end{array}$ & $\begin{array}{c}\text { mean } \pm S . D . \\
64 \pm 6.6 \\
68 \pm 3.5 \\
68 \pm 4.8 \\
76 \pm 2.5 \\
64 \pm 1.3 \\
72 \pm 1.7 \\
67 \pm 2.1 \\
63 \pm 3.0 \\
67 \pm 2.1 \\
73 \pm 4.5 \\
66 \pm 2.6\end{array}$ & $\begin{array}{l}3 \\
3 \\
2 \\
3 \\
2 \\
2 \\
2 \\
3 \\
2 \\
3 \\
3\end{array}$ & $\begin{array}{c}\text { mean } \pm S . D . \\
74 \pm 2.8 \\
78 \pm 4.2 \\
73 \pm 4.0 \\
83 \pm 4.0 \\
71 \pm 4.5 \\
67 \pm 3.6 \\
69 \pm 1.0 \\
70 \pm 3.5 \\
62 \pm 3.5 \\
74 \pm 2.4 \\
70 \pm 4.2\end{array}$ & $\begin{array}{r}3.13 \\
4.00 \\
1.61 \\
3.33 \\
3.33 \\
2.50 \\
2.00 \\
3.33 \\
2.78 \\
.43 \\
1.74\end{array}$ \\
\hline
\end{tabular}

Of 4 negative period changes, 3 were increases, 1 decrease.

Of 2 positive period changes, 2 were increases, 0 decreases.

Of 5 control period changes, 4 were increases, 1 decrease.

This analysis may be summarized with the statement that using the means of five observations on each subject for comparison values, 66 comparisons on each of five variables (metabolism, systolic blood pressure, diastolic blood pressure, respiratory rate, pulse rate) yielded only ten cases (out of a total of $5 \times 66,330$ ) in which the Critical Ratio of an observed change exceeded 3. Only one subject occurred twice in this total (K). Five of the ten exceeding a Critical Ratio of 3 occurred in the Control Series, four in the Positive Series, and one in the Negative Series. None of these results justify the conclusion that any one of the variables concerned has been consistently affected or that any subject has shown any consistent response to ionization.

The data on oral temperature and urine volume were entirely negative and are not reproduced here.

\section{GROUP RESULTS}

The inspection of the individual results makes it clear that no individual case can be regarded as "susceptible" to the effects of ionized air, in so far as the measures used may be accepted as adequate measures of such effects. The group data can only bear this out more clearly.

TABLE VIII

Metabolic rate (grand averages)

(in total calories per hour). Consolidated results

\begin{tabular}{|c|c|c|c|c|c|}
\hline $\begin{array}{c}\bullet \\
\text { Series }\end{array}$ & $\begin{array}{l}\text { Num- } \\
\text { ber of } \\
\text { sub- } \\
\text { jects }\end{array}$ & $\begin{array}{l}\text { Num- } \\
\text { ber of } \\
\text { experi- } \\
\text { ments }\end{array}$ & $\begin{array}{l}\text { 1st period } \\
\text { normal }\end{array}$ & $\begin{array}{c}2 d \text { period } \\
\text { ions }\end{array}$ & $\begin{array}{l}\text { 3d period } \\
\text { normal }\end{array}$ \\
\hline Positive... & 11 & 53 & $\begin{array}{c}\text { mean } \pm S . D . \\
a \\
67.3 \pm 6.5\end{array}$ & $\begin{array}{c}\text { mean } \pm S . D \\
b \\
68.3 \pm 5.5\end{array}$ & $\begin{array}{c}\text { mean } \pm S . D . \\
c \\
67.8 \pm 6.3\end{array}$ \\
\hline Negative. . & 11 & 53 & ${ }_{67.7}^{d} \pm 6.0$ & $67.2^{e} \pm 5.6$ & $\underset{68.0^{f} \pm 6.5}{f}$ \\
\hline Control.. & 11 & 53 & $68.2^{g} \pm 5.7$ & $\begin{array}{c}h^{*} \\
67.9 \pm 4.9\end{array}$ & $68.8^{i} \pm 5.7$ \\
\hline
\end{tabular}

* No ions.

\begin{tabular}{cc}
\multicolumn{3}{c}{$\begin{array}{c}\text { Significance of the difference } \\
\text { Difference } \\
\text { between means }\end{array}$} & $\begin{array}{c}\text { Critical } \\
\text { ratio }\end{array}$ \\
$\begin{array}{c}\text { Comparison } \\
\text { 1. Cells } a \text { to } g \ldots \ldots \ldots \ldots \ldots .9\end{array}$ \\
2. Cells $a$ to $b \ldots \ldots \ldots \ldots .0$ & .34 \\
3. Cells $e$ to $i \ldots \ldots \ldots \ldots \ldots 1.6$ & .83 \\
TABLE IX & .66
\end{tabular}

Blood pressure (systolic) (in mm. of $\mathrm{Hg}$ ). Consolidated results

\begin{tabular}{|c|c|c|c|c|c|}
\hline Series & $\begin{array}{l}\text { Num- } \\
\text { ber of } \\
\text { sub- } \\
\text { jects }\end{array}$ & $\begin{array}{l}\text { Num- } \\
\text { ber of } \\
\text { experi- } \\
\text { ments }\end{array}$ & $\begin{array}{l}\text { 1st period } \\
\text { normal }\end{array}$ & $\underset{\text { ions }}{2 d}$ & $\begin{array}{l}\text { 3d period } \\
\text { normal }\end{array}$ \\
\hline Positive... & 11 & 53 & $\begin{array}{c}\text { mean } \pm S . D . \\
a \\
106 \pm 7.4\end{array}$ & $\begin{array}{c}\text { mean } \pm S . D . \\
b \\
105 \pm 5.7\end{array}$ & $\begin{array}{c}\text { mean } \pm S . D \\
c \\
107 \pm 6.0\end{array}$ \\
\hline Negative .. & 11 & 53 & $104 \stackrel{d}{ \pm} 7.3$ & ${ }_{104}^{e} \pm 5.2$ & $105 \pm 4.6$ \\
\hline Contro & 11 & 53 & $105^{g} \pm 8.1$ & $\begin{array}{c}h^{*} \\
105 \pm 7.6\end{array}$ & $106^{i} \pm 7.8$ \\
\hline
\end{tabular}

* No ions.

\begin{tabular}{lc}
\multicolumn{3}{c}{$\begin{array}{c}\text { Significance of the difference } \\
\text { Difference } \\
\text { between means }\end{array}$} & $\begin{array}{c}\text { Critical } \\
\text { ratio }\end{array}$ \\
$\begin{array}{c}\text { Comparison } \\
\text { 1. Cells } a \text { to } d \ldots \ldots \ldots \ldots \ldots .2 .0\end{array}$ & .64 \\
2. Cells $d$ to $f \ldots \ldots \ldots \ldots \ldots 1.0$ & .39 \\
3. Cells $e$ to $c \ldots \ldots \ldots \ldots \ldots .0$ & 1.26
\end{tabular}


TABLE $\mathbf{X}$

Blood pressure (diastolic) (in mm. of $\mathrm{Hg}$ ). Consolidated results

\begin{tabular}{c|c|c|c|c|c}
\hline \hline Series & $\begin{array}{c}\text { Num- } \\
\text { ber of } \\
\text { sub- } \\
\text { jects }\end{array}$ & $\begin{array}{c}\text { Num- } \\
\text { ber of } \\
\text { experi- } \\
\text { ments }\end{array}$ & $\begin{array}{c}\text { 1st period } \\
\text { normal }\end{array}$ & $\begin{array}{c}\text { 2d period } \\
\text { ions }\end{array}$ & $\begin{array}{c}\text { 3d period } \\
\text { normal }\end{array}$ \\
\hline Positive... & 11 & 53 & $\begin{array}{r}\text { mean } \pm \text { S.D.D. } \\
a \\
67 \pm 5.7\end{array}$ & $\begin{array}{c}\text { mean } \pm \text { S.D. } \\
b \\
69 \pm 4.7\end{array}$ & $\begin{array}{c}\text { mean } \pm \text { S.D. } \\
c \\
69 \pm 4.2\end{array}$ \\
\hline Negative .. & 11 & 53 & $\begin{array}{c}d \\
69 \pm 3.5\end{array}$ & $\begin{array}{c}e \\
69 \pm 3.6\end{array}$ & $\begin{array}{c}f \\
71 \pm 3.2\end{array}$ \\
\hline Control.... & 11 & 53 & $\begin{array}{c}g \\
694.2\end{array}$ & $\begin{array}{c}h^{*} \\
69 \pm 4.2\end{array}$ & $\begin{array}{c}i \\
71 \pm 47 .\end{array}$ \\
\hline
\end{tabular}

* No ions.

\begin{tabular}{|c|c|c|}
\hline \multicolumn{3}{|c|}{ Significance of the difference } \\
\hline $\begin{array}{l}\text { Comparison } \\
\text { 1. Cells } a \text { to } d \text {. } \\
\text { 2. Cells } d \text { to } f \text {. } \\
\text { 3. Cells } a \text { to } f . \text {. }\end{array}$ & $\begin{array}{l}\begin{array}{c}\text { Difference } \\
\text { between mean }\end{array} \\
\ldots \ldots 2 \\
\ldots \ldots .2 \\
\ldots \ldots .4\end{array}$ & $\begin{array}{c}\text { Critical } \\
\text { ratio } \\
.99 \\
1.42 \\
2.02\end{array}$ \\
\hline
\end{tabular}

TABLE XI

Respiratory rate (per minute). Consolidated results for 11 subjects

\begin{tabular}{|c|c|c|c|c|c|}
\hline Series & $\begin{array}{l}\text { Num- } \\
\text { ber of } \\
\text { sub- } \\
\text { jects }\end{array}$ & $\begin{array}{l}\text { Num- } \\
\text { ber of } \\
\text { experi- } \\
\text { ments }\end{array}$ & $\begin{array}{c}\text { 1st period } \\
\text { normal }\end{array}$ & $\begin{array}{c}2 \mathrm{~d} \text { period } \\
\text { ions }\end{array}$ & $\begin{array}{l}\text { 3d period } \\
\text { normal }\end{array}$ \\
\hline ositive... & 11 & 53 & $\begin{array}{c}\text { mean } \pm S . D . \\
a \\
11.4 \pm 3.1\end{array}$ & $\begin{array}{c}\operatorname{mean} \pm S . D . \\
b \\
11.2 \pm 3.1\end{array}$ & $\begin{array}{c}\text { mean } \pm S . D . \\
c \\
11.3^{c} \pm 3.5\end{array}$ \\
\hline legative . . & 11 & 53 & $\stackrel{d}{d 1.7} \pm 2.8$ & $\stackrel{e}{e}{ }^{11.3^{ \pm}} \pm 3.2$ & $\stackrel{f}{f}$ \\
\hline & 11 & 53 & $11.6^{g} \pm 2.6$ & $\begin{array}{c}h^{*} \\
11.8 \pm 2.8\end{array}$ & $11.2^{i} \pm 3.0$ \\
\hline
\end{tabular}

* No ions.

\begin{tabular}{lc}
\multicolumn{4}{c}{$\begin{array}{c}\text { Significance of the difference } \\
\text { Difference } \\
\text { between means }\end{array}$} & $\begin{array}{c}\text { Critical } \\
\text { ratio }\end{array}$ \\
$\begin{array}{c}\text { Comparison } \\
\text { 1. Cells } a \text { to } d \ldots \ldots \ldots \ldots \ldots . .3\end{array}$ \\
2. Cells $g$ to $i \ldots \ldots \ldots \ldots \ldots .4$ \\
3. Cells $h$ to $i \ldots \ldots \ldots \ldots \ldots .6$ & .24 \\
\end{tabular}

In Tables VIII to XII inclusive, are summarized the consolidated results on all eleven subjects for each of the physiological measures. For each table the significance of the difference has been computed for three comparisons which have been conveniently designated as Comparison 1, 2 and 3 , as follows:

Comparison 1: The greatest difference observed between any two of the three "first normal" pe- riods (in Table VIII this involves cells $a$ and $g$ ) -the three columns of figures in the upper line being designated from left to right as $a, b, c$, those in the second line as $d, e, f$, and those in the third line as $g, h, i$.

TABLE XII

Pulse rate (per minute). Consolidated results

\begin{tabular}{|c|c|c|c|c|c|}
\hline Series & $\begin{array}{l}\text { Num- } \\
\text { ber of } \\
\text { sub- } \\
\text { jects }\end{array}$ & $\begin{array}{l}\text { Num- } \\
\text { ber of } \\
\text { experi- } \\
\text { ments }\end{array}$ & $\begin{array}{l}\text { 1st period } \\
\text { normal }\end{array}$ & $\begin{array}{l}2 d \text { period } \\
\text { ions }\end{array}$ & $\begin{array}{l}\text { 3d period } \\
\text { normal }\end{array}$ \\
\hline Positive... & 11 & 53 & $\begin{array}{c}\text { mean } \pm \text { S.D. } \\
a \\
60.9 \pm 7.1\end{array}$ & $\begin{array}{c}\operatorname{mean} \pm S . D . \\
b \\
59.8 \pm 6.2\end{array}$ & $\begin{array}{c}\operatorname{meax} \pm S . D \\
c \\
60.7 \pm 6.0\end{array}$ \\
\hline Negative.. & 11 & 53 & $60.2 \stackrel{d}{ \pm} 6.6$ & $\stackrel{e}{59.6 \pm 6.6}$ & $\underset{60.6 \pm 5.9}{f}$ \\
\hline Control.... & 11 & 53 & $61.1^{g} \pm 8.1$ & $\begin{array}{c}h^{*} \\
60.5 \pm 8.0\end{array}$ & 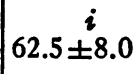 \\
\hline
\end{tabular}

Significance of the difference

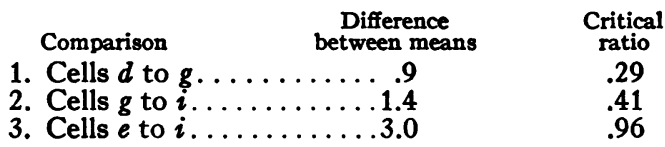

Comparison 2: The greatest difference between any "first normal" period and any succeeding period in the same series (in Table VIII, cells $a$ and $b$ ).

Comparison 3: The greatest difference between any two of the 9 cells regardless of the series in which it occurs (in Table VIII, cells $e$ and $i$ ).

An inspection of these comparisons for Tables VIII to XII reveals no instance of a reliable difference. In Table VIII (metabolic rate) the direction of the change is slggestive in the Positive and Negative Series, but statistically not significant. Even the suggestion of an opposed effect does not occur in the other tables of this series. It may be noted that the absence of any significant difference between cells $a$ and $d$, and $d$ and $g$ negatives the possibility of any cumulative effect of five successive treatments with ionized air of either sign.

If we forget for the moment Critical Ratios, and tabulate for each variable the observed values according to the series in which they occurred it is found that summing all five variables the greatest variation occurred 19 times in the Control Series, 19 times in the Positive Series, and 17 times 
in the Negative Series. The variations are distributed as nearly in the theoretical chance ratio as is possible with integers, a population of 55 and 3 classifications. (In this comparison, group means are used. See Tables VIII to XII.)

\section{Normalizing effects}

As was mentioned earlier in this paper Yaglou and his associates (4), using light ions, could find no opposed effects from the use of positive and negative ionized air, but did suggest tentatively, that "ionized air" irrespective of polarity may have a "normalizing" effect upon these physiological functions. It would certainly appear upon inspection of their tables that this is true. In the case of basal metabolism, as an example, initial tests in normal air which fell between 75 and 84 per cent of the normal standard averaged 81 per cent of normal, and on exposure to ionized air showed an average change of +12.7 per cent. Likewise cases falling between 115 and 124 per cent of normal averaged 121 per cent of normal in ordinary air; and on exposure to ionized air showed an average decrease of -9.0 per cent. Tabulations for all variables for both morning and afternoon groups, and for all age groups, showed essentially the same effect.

It seems to us, however, that precisely this effect is to be expected in any distributive arrangement of measurements of this type. Any single measure, as of metabolic rate, is in a sense, a fallible measure in so far as it deviates from the most probable value under fixed conditions of measurement (namely, the mean of a series of such measurements). Large deviations from a mean value occur less frequently than small deviations, and having occurred, successive measures (the true mean remaining stable) are likely to show either a positive or negative regression toward the mean. If each of 10 subjects shows a basal metabolic rate of 80 per cent of normal (unless there has been a very selective sampling of low basal metabolic rates from the total population) successive tests will usually show a regression of some degree toward the normal of the population.

In this particular instance the critical test of the "normalizing" effect is a comparison with a control series on the same group of subjects.

In Table XIII and Table XIV the data of this study on metabolic rate and blood pressure have been arranged in the distributive manner, both for the consolidated measures of the Positive and Negative Series and for the Control Series. An inspection of these tables demonstrates that the " normalizing" effect is a statistical characteristic of the classification of repeated measures distributed about a mean, and occurs as strikingly in the Control Series as it does in the consolidated ion series.

TABLE XIII

Metabolic changes during exposure to ionization. (With Control Series)

\begin{tabular}{|c|c|c|c|c|c|}
\hline \multirow{2}{*}{ Basal observations and observations 2 hours after standard lunch } & \multicolumn{5}{|c|}{$\begin{array}{c}\text { Heat production in normal air in percentage of } \\
\text { DuBois basal standards }\end{array}$} \\
\hline & $\begin{array}{l}75-84 \\
(A)\end{array}$ & $\stackrel{85-94}{(B)}$ & $\begin{array}{l}95-104 \\
(C)\end{array}$ & $\begin{array}{l}105-114 \\
(D)\end{array}$ & $\underset{(E)}{115-124}$ \\
\hline 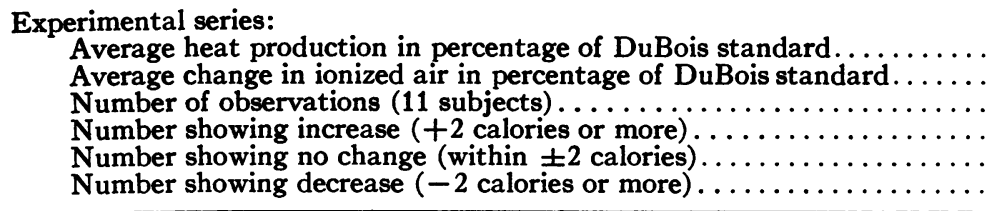 & $\begin{array}{c}80.7 \\
+5.0 \\
4 \\
3 \\
1 \\
0\end{array}$ & $\begin{array}{c}89.8 \\
+2.9 \\
39 \\
17 \\
16 \\
6\end{array}$ & $\begin{array}{c}99.3 \\
\pm .0 \\
47 \\
14 \\
15 \\
18\end{array}$ & $\begin{array}{c}107.4 \\
-3.1 \\
14 \\
2 \\
3 \\
9\end{array}$ & $\begin{array}{c}118.7 \\
-10.0 \\
2 \\
0 \\
0 \\
2\end{array}$ \\
\hline 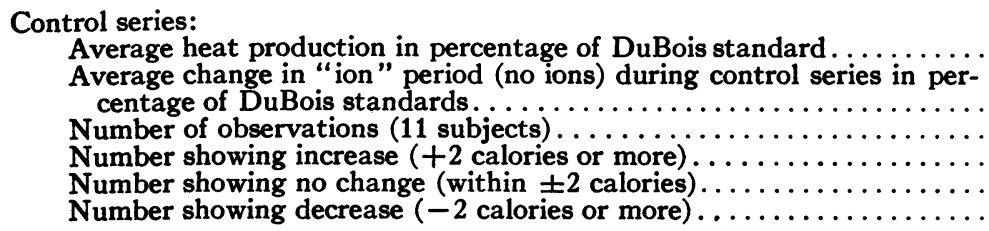 & $\begin{array}{r}83.0 \\
+6.7 \\
3 \\
2 \\
1 \\
0\end{array}$ & $\begin{array}{r}91.1 \\
+2.0 \\
17 \\
4 \\
11 \\
2\end{array}$ & $\begin{array}{c}98.5 \\
-1.4 \\
20 \\
1 \\
13 \\
6\end{array}$ & $\begin{array}{c}109.2 \\
-3.9 \\
13 \\
3 \\
3 \\
7\end{array}$ & \\
\hline
\end{tabular}


TABLE XIV

Change in systolic blood pressure during exposure to ionized air. (With Control Series)

\begin{tabular}{|c|c|c|c|c|c|c|}
\hline \multirow{2}{*}{ Consolidated results of morning and afternoon observations } & \multicolumn{6}{|c|}{ Systolic blood pressure in normal air $(\mathrm{mm} . \mathrm{Hg})$} \\
\hline & Under 90 & 90-99 & $100-109$ & $110-119$ & $120-129$ & Over 130 \\
\hline 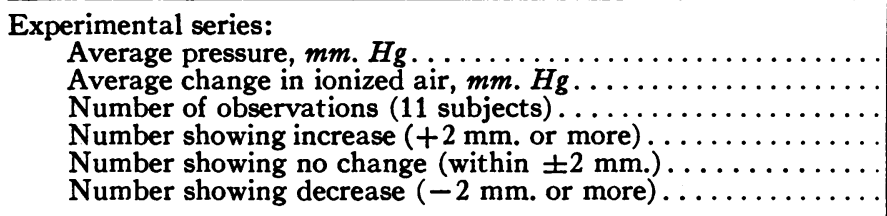 & $\begin{array}{c}88.0 \\
+6.0 \\
1 \\
1 \\
0 \\
0\end{array}$ & $\begin{array}{c}95.1 \\
+3.5 \\
30 \\
17 \\
11 \\
2\end{array}$ & $\begin{array}{c}104.0 \\
+. .2 \\
45 \\
10 \\
25 \\
10\end{array}$ & $\begin{array}{c}113.9 \\
-3.3 \\
24 \\
1 \\
10 \\
13\end{array}$ & $\begin{array}{c}121.6 \\
-\quad 3.6 \\
5 \\
0 \\
1 \\
4\end{array}$ & $\begin{array}{c}130.0 \\
-10.0 \\
1 \\
0 \\
4 \\
1\end{array}$ \\
\hline 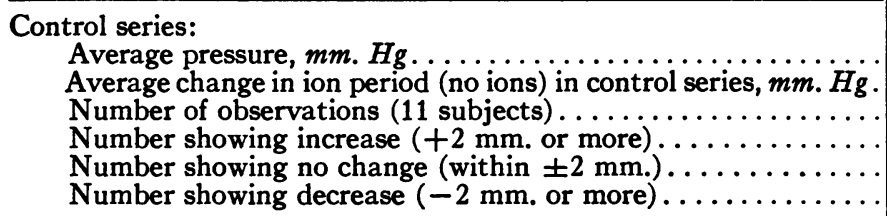 & & $\begin{array}{c}95.0 \\
+1.1 \\
18 \\
4 \\
13 \\
1\end{array}$ & $\begin{array}{c}103.1 \\
-1.3 \\
16 \\
2 \\
10 \\
4\end{array}$ & $\begin{array}{c}113.3 \\
-2.4 \\
17 \\
5 \\
4 \\
8\end{array}$ & $\begin{array}{c}120.0 \\
-11.0 \\
2 \\
0 \\
0 \\
2\end{array}$ & \\
\hline
\end{tabular}

SUBJECTIVE SENSATIONS

At the beginning of this study it was planned to make a check list of the subjective reactions reported by Dessauer (1) and Yaglou (2) and to have it filled out by subjects after each experimental period. Early exploratory experiments with subjects not used in this study $(\mathrm{Cr}, \mathrm{Ro}, \mathrm{Hn}$, Herr) indicated, however, that such a procedure was of doubtful value. It was evident that the check list would measure, in all probability, the subjects' suggestibility more accurately than his psychic reactions, if any, to ionized atmospheres.

With this in mind it was decided to give the subject a chance to express his own impression of his condition. The question was simply, "How did you feel during the experimental period? What comments have you to make?" In Table $\mathrm{XV}$ these reactions are classified under the categories built up by the subject's own initiative. There seem to be no good grounds for stating that these reactions reveal anything more than the fact that a three-hour period of complete rest results in drowsiness, and that the continual exposure of the face to an air stream of sensible velocity produces drying of the lips and throat, under conditions of low to medium relative humidity.

Some of the subjects learned of the general nature of the study after the experiment had been under way for some time. None of the subjects at the end of the experiment could distinguish the Control Series from the Positive or Negative Series, nor had they realized that each separate ex-
TABLE XV

Tabulation of frequency of certain comments made by subjects

\begin{tabular}{|c|c|c|c|}
\hline & $\begin{array}{c}\text { Positive } \\
\text { ions }\end{array}$ & $\begin{array}{c}\text { Negative } \\
\text { ions }\end{array}$ & $\begin{array}{c}\text { Control } \\
\text { series }\end{array}$ \\
\hline Difficult breathing*. & $\begin{array}{c}\text { frequency } \\
5\end{array}$ & frequency & frequency \\
\hline Drowsy, sleepy..... & 13 & 12 & $\begin{array}{l}1 \\
8\end{array}$ \\
\hline Bad taste in mouth...... & 2 & 0 & $\begin{array}{l}0 \\
1\end{array}$ \\
\hline Throat dry $\ldots \ldots \ldots \ldots \ldots$ & 3 & 1 & 3 \\
\hline Lips dry . . . . . . . . . & 9 & 3 & 6 \\
\hline Watering of the eyes..... & 0 & 4 & 2 \\
\hline Headache............ & 3 & 3 & 0 \\
\hline Tired, depressed. . & 0 & 3 & 3 \\
\hline Face hot ...... & 1 & 4 & 1 \\
\hline Face cool. . . . . . . . & 4 & 2 & $\mathbf{0}$ \\
\hline Feel good, stimulated & 4 & 4 & 1 \\
\hline Feel normal. ........ & 14 & 11 & 7 \\
\hline No comments.... & 19 & 16 & 22 \\
\hline
\end{tabular}

* This item refers to breathing into and out of the metabolism apparatus. Difficulty disappears with practice.

perimental period was divided into sections during one of which they had received ionized air. Two subjects knew that negative ions were "stimulating " and that positive ions were " depressing." These subjects were no more successful than the others in distinguishing the periods, nor did their comments vary in any significant way in the Positive Series and the Control Series. None of the other subjects had any conception of the reported effects of ionized air.

If we consider that the first nine lines in Table XIV represent undesirable sensations and lines 10 and 11 (face cool; feels good, stimulated) repre- 
sent desirable sensations, we find the following distribution of opinion:

Sensations reported per experiment

\begin{tabular}{l|c|c|c}
\hline \hline & Positive ions & Negative ions & Control series \\
\hline Undesirable.... & .68 & .58 & .45 \\
Desirable...... & .15 & .11 & .01 \\
\hline
\end{tabular}

The slight differences which appear may probably be attributed to the order in which the experiments were performed, both pleasant and unpleasant sensations being sought for by the subjects with more ardor in the first series of tests with positive ions,-an ardor which decreased as routine dulled their interest.

It seems possible that light ions such as were used by Yaglou may produce certain cutaneous sensations (possibly due to the collection of static charges on body hair) which do not occur with the heavy ions used in this study and administered in the manner described.

\section{SUMMARY}

The experimental group comprised 11 male subjects in normal health with an age range of from 18,8 months to 25,8 months. One hundred and fifty-nine experiments each extending over a period of $3 \frac{1}{2}$ hours were made. Fiftythree of these were experiments in which positive ions were administered during a 30-minute period preceded and followed by similar control periods. In each of the 3 periods the physiological measurements were repeated. In 53 experiments this routine was repeated with negative ions. In a third series 53 control experiments were made in which the middle or "ionized" air period did not contain ions. Throughout the entire series the apparatus employed for the generation of ionized particles operated as usual with the single exception that ions either were or were not added to the air stream.

The respiration of positive or negative ions (mobility .007 to $.0018 \mathrm{~cm}$. per second per volt per centimeter) in a concentration of 5 . to $6 . \times$ $10^{\circ}$ ions per cubic centimeter of air produces no consistent or reliable effect upon the metabolic rate, systolic or diastolic blood pressure, pulse rate, rate of respiration, oral temperature, or urine volume of healthy, apparently normal young male subjects. Subjective sensations reported by subjects reveal no effects related specifically to the administration of ionized air.

In conclusion it must be said that these experiments do not close the question as to possible cumulative effects of ordinary atmospheric ionization or artificial ionization on health or comfort. Nor do they justify the conclusion that "artificially ionized air" has no effect upon any physiological function or comfort factor. They certainly do tend to justify the opinion that, so far as normal subjects are concerned, such effects are unproven and improbable. As in Yaglou's later experiments, " nothing definite was found to justify the use of artificial ionization in general ventilation." There still remains the question of the reaction of pathological subjects, in particular, cases of essential hypertension, to ionized air. This problem will be dealt with in a later paper from this laboratory.

\section{BIBLIOGRAPHY}

1. Dessauer, F., Zehn Jahre Forschung auf dem Physikalish-Medizinischen Grenzgebeit. Georg Thieme, Leipzig, 1931.

2. Yaglou, C. P., Brandt, A. D., and Benjamin, L. C., Observations on a group of subjects before, during, and after exposure to ionized air. J. Indust. Hyg., 1933, 15, 341.

3. Benedict, C. G., and Benedict, F. G., A permissible breakfast prior to basal metabolism measurements. Boston M. and S. J., 1923, 88, 849.

4. Yaglou, C. P., Brandt, A. D., and Benjamin, L. C., Physiologic changes during exposure to ionized air. Heating, Piping and Air Conditioning, 1933, $8,423$.

5. Rugg, H. O., Statistical Methods Applied to Education. Houghton-Mifflin Co., New York, 1917.

6. Küster, E., Gasstoff wechselbestimmungen mit dem Simonsonschen Apparat an ruhenden Personen bei Wetterfertiger-Anemostaten-lüftung. Arb. a. d. Staatsinst. f. exper. Therap., 1932, 26, 21. 